\title{
Isolation of Clostridium perfringens and C. difficile in crab-eating fox (Cerdocyon thous - Linnaeus 1776) from Northeastern Brazil
}

\author{
[Isolamento de Clostridium perfringens $e$ C. difficile em cachorro-do-mato \\ (Cerdocyon thous - Linnaeus 1776) da região Nordeste do Brasil] \\ J.C. Almeida ${ }^{1}$, R.O.S. Silva ${ }^{2}$, F.C.F. Lobato ${ }^{2}$, R.A. Mota ${ }^{1 *}$ \\ ${ }^{1}$ Universidade Federal Rural de Pernambuco - Recife, PE \\ ${ }^{2}$ Universidade Federal de Minas Gerais - Belo Horizonte, MG
}

\begin{abstract}
The aim of the present study was to isolate Clostridium perfringens and C. difficile in crab-eating fox (Cerdocyon thous) from Northeastern Brazil. Stool samples of 18 captive crab-eating foxes from four states of Northeastern Brazil (Alagoas, Bahia, Paraíba e Pernambuco) were collected and subjected to $C$. perfringens and $C$. difficile isolation. Suggestive colonies of $C$. perfringens were then analyzed for genes encoding the major $C$. perfringens toxins (alpha, beta, epsilon and iota), beta-2 toxin (cpb2), enterotoxin (cpe), and NetB- (netB) and NetF- (netF) encoding genes. C. difficile strains were analyzed by multiplexPCR for a housekeeping gene $(t p i)$, toxins $\mathrm{A}(t c d A)$ and $\mathrm{B}(t c d B)$ and a binary toxin gene $(c d t B)$. Unthawed aliquots of stool samples positive for toxigenic $C$. difficile were subjected to a commercial ELISA to evaluate the presence of A/B toxins. Clostridium perfringens (type A) was isolated from five (27\%) samples, and only one sample was positive for beta-2 enconding gene (cpb2). Two (11\%) stool samples were positive for $C$. difficile, but negative for A/B toxins. These two wild canids were also positive for $C$. perfringens type A. This is the first report of $C$. difficile in crab-eating fox.
\end{abstract}

Keywords: diarrhea, carnivores, wild canids

\section{RESUMO}

O objetivo deste estudo foi isolar Clostridium perfringens $e$ C. difficile em cachorro-do-mato (Cerdocyon thous) da região Nordeste do Brasil. Amostras de fezes de 18 cachorros-do-mato mantidos em cativeiro e oriundos de quatro estados da região Nordeste do Brasil (Alagoas, Bahia, Paraíba e Pernambuco) foram coletadas e submetidas a isolamento de C. perfringens $e$ C. difficile. As colônias sugestivas de C. perfringens foram analisadas para os genes que codificam as principais toxinas de C. perfringens (alfa, beta, épsilon e iota), toxina beta-2 (cpb2), enterotoxina (cpe) e NetB- (netB) e NetF- (netF). As cepas de C. difficile foram analisadas por PCR-multiplex para o gene tpi, toxinas $A(\operatorname{tcd} \mathrm{A})$ e $B(\operatorname{tcdB})$ e um gene de toxina binária (cdtB). Alíquotas de amostras de fezes positivas para $\mathrm{C}$. difficile toxigênico foram submetidas a um ELISA comercial para avaliar a presença de toxinas A/B. Clostridium perfringens (tipo A) foi isolado de cinco (27\%) amostras, e apenas uma amostra foi positiva para o gene da toxina beta-2 (cpb2). Duas (11\%) amostras de fezes foram positivas para C. difficile, mas negativas para toxinas A/B. Estes dois canídeos silvestres também foram positivos para C. perfringens tipo A. Este é o primeiro relato de C. difficile em cachorro-do-mato.

Palavras-chave: diarreia, carnívoros, canídeos silvestres

\section{INTRODUCTION}

The crab-eating fox (Cerdocyon thous) is a member of the Canidae family and is widely distributed in South America countries, including

Recebido em 15 de março de 2017

Aceito em 17 de janeiro de 2018

*Autor para correspondência (corresponding author)

E-mail: rinaldo.mota@hotmail.com
Colombia, Venezuela, Paraguay, Uruguay, Argentina and Brazil. Recent studies have suggested that $C$. thous could act as a reservoir of some pathogens, including some responsible for re-emerging diseases like visceral leishmaniais, brucellosis, canine rangeliosis and rabies 
(Carnieli Jr. et al., 2009, Oliveira-Filho et al., 2012, Soares et al., 2014, Tunon et al., 2015). The concern about the transmission of diseases from this wild specie to humans and also to domestic animals is increasing in light of the expansion of urban areas at the expense of areas with native vegetation (Souza et al., 2016).

Clostridium perfringens and $C$. difficile are Gram-positive sporogenic anaerobic bacterium and are recognized as pathogens responsible for intestinal disease in human and animals (Silva and Lobato et al., 2015, Rodriguez et al., 2016). C. perfringens is commonly found in the enteric microbiota of healthy animals but also responsible for a several diseases in humans and animals. C. perfringens strains are divided into five types (from A to E) according to four major toxins (alpha, beta, epsilon and iota), while some additional toxins have been associated with intestinal infections (Uzal et al., 2014). The screening for virulence factors genes could contribute to the knowledge of $C$. perfringens epidemiology in wild animals but, despite few studies, the main genotypes and the most common additional virulence factors of $C$. perfringens strains isolated from Canidae are largely unknown (Silva et al., 2016). C. difficile produces toxin $\mathrm{A}$ and toxin $\mathrm{B}$, known as the main virulence factors of this microorganism. Some strains may also produce a binary toxin (CDT) associated with enhanced virulence (Schwan et al., 2009). C. difficile infection (CDI) commonly occurs in elderly hospitalized patients submitted to antibiotic therapy, so CDI is recognized as a primarily nosocomial disease (Loo et al., 2011). On the other hand, this concept is now being challenged due cases of CDI reported in populations without any previous antibiotic therapy or hospitalization (Hensgens et al., 2012). Some studies have also shown a genetic overlap from $C$. difficile strains from humans and animals, suggesting it might be a zoonotic pathogen (Knetsch et al., 2014).

In light of this, the purpose of this study was to isolate $C$. perfringens and $C$. difficile in crabeating fox (Cerdocyon thous) from Northeastern Brazil.

\section{MATERIAL AND METHODS}

This study was carried out in accordance with the Ethical Principles in Animal Research adopted by the Brazilian College of Animal Experimentation and was approved by the Animal Use Ethics Committee from Universidade Federal Rural de Pernambuco (license number 27/2015) and by the Brazilian Institute for the Environment and Renewable Natural Resources (IBAMA) under number 47677.

Captive crab-eating foxes ( $C$. thous) from different states of Northeastern Brazil were sampled by this study as follows: eight animals from Pernambuco, three animals from Alagoas, four from Bahia and ten from Paraíba. Chemical restraint (1\% xylazine hydrochloride and $10 \%$ cetamine hydrochloride) was required. In Paraíba state was not possible to collect fecal samples individually due to local management conditions; thereby the crab-eating foxes were grouped according to their relationship to each other, resulting in three pools of stool samples. In this specific case, fresh fecal samples were collected manually from the ground. Thus, eighteen fecal specimens (15 individually samples and three pools) were collected in sterile containers and were kept cool at $-20^{\circ} \mathrm{C}$ until further processing. None of the sampled animals had diarrhea or any other clinical signs previously or at the sampling moment.

To perform the isolation of $C$. perfringens, 0.08 $0.12 \mathrm{~g}$ of feces were serially diluted by factors of 10 , ranging from $10^{-1}$ to $10^{-3}$. Aliquots of $10 \mu \mathrm{l}$ of each dilution were plated on sulfite polymyxin sulfadiazine agar (Difco Laboratories, Detroit, MI, USA) and were anaerobically incubated at $37^{\circ} \mathrm{C}$ for 24 hours. After incubation, all sulfatereducing colonies from each dilution were subjected to a previously described PCR protocol (Vieira et al., 2008) for the detection of genes encoding the major $C$. perfringens toxins (alpha, beta, epsilon and iota), beta-2 toxin (cpb2) and enterotoxin (cpe). The PCR protocol described by Keyburn et al. (2008) and Gohari et al. (2015) was applied for the detection of the NetB-and NetF-encoding genes (netB and netF, respectively). The PCR product was subjected to electrophoresis in $2 \%$ agarose gel stained with ethidium bromide (Sigma-Aldrich Co., St. Louis, MO, USA). The bands were visualized under ultraviolet light in a photodocumentation system. 
The isolation of $C$. difficile spores was carried out as follows: equal volumes of fecal samples and $96 \%$ ethanol $(\mathrm{v} / \mathrm{v})$ were mixed. After incubation at room temperature for 30 minutes, $50 \mu 1$ aliquots were inoculated on plates contained with $7 \%$ horse blood and $0.1 \%$ sodium taurocholate (Sigma-Aldrich Co., St. Louis, MO, USA). After anaerobic incubation at $37^{\circ} \mathrm{C}$ for at least 72 hours, all colonies with suggestive morphology were subjected to a multiplex-PCR for a housekeeping gene (tpi), toxins A $(t c d A)$ and $\mathrm{B}(t c d B)$ and a binary toxin gene $(c d t B)$. Unthawed aliquots of stool positive samples for C. difficile were subjected to a commercial enzyme-linked immunosorbent assay (ELISA) kit to evaluate the presence of $\mathrm{A} / \mathrm{B}$ toxins $(C$. difficileTox A/B II - Techlab Inc., Blacksburg, VA, USA).

\section{RESULTS AND DISCUSSION}

C. perfringens was isolated from $27 \%(5 / 18)$ samples, all genotyped as type A. Four positive samples were detected in animals from Pernambuco. The other positive sample was a pool of fecal sample of three adults crab-eating foxes from Paraíba. The isolation of $C$. perfringens type $\mathrm{A}$ and the absence of other genotypes corroborate previous studies with some Canidae species (Silva et al., 2014a). It is also interesting to note that only one sample, obtained from Pernambuco state, was positive for beta-2 enconding gene ( $c p b 2)$, while Silva et al. (2014a) reported $34.6 \%$ rate in a study with several carnivore species including $C$. thous, Puma concolor (cougar), Leopardus tigrinus (oncilla), Leopardus pardalis (ocelot), Chrysocyon brachyurus (maned wolf) and others. Other additional toxin genes, including enterotoxin (cpe), NetB (netB) and the recently described NetF (netF) were not detected in the present study.

All positive crab-eating foxes were asymptomatic at the sampling moment and there were no previous episodes of diarrhea, so the isolated $C$. perfringens by the present study might be part of their microbiota. However severe clinical cases of $C$. perfringens infection in wild carnivores have been described, such as the death of a Siberian tiger (Panthera tigris altaica) and a lion (Panthera leo) by hemorrhagic enterocolitis caused by $C$. perfringens type A (Zhang et al., 2012) and a suspected case of neurotoxicity in a tiger $(P$. tigris) due to $C$. perfringens type B (Zeira et al., 2012). Despite the known potential of $C$. perfringens as an enteropathogen for wild Canidae and Felidae, virulence factors involved in enteric disease are still clouded. Recent studies described two novel pore-forming toxins (NetF and NetB) that are clearly associated with necrotic enteritis and hemorrhagic diarrhea in dogs and broiler chicken, respectively (Keyburn et al., 2008, Gohari et al., 2015). Further studies, including diarrheic animals, are essential to clarify if any of the described toxin genes could be used as a virulence marker for C. perfringens isolated from wild carnivore species.

Two $(11 \%)$ stool samples were positive for $C$. difficile (Figure 1), but negative for $\mathrm{A} / \mathrm{B}$ toxins by ELISA. These strains, one toxigenic $(\mathrm{A}+\mathrm{B}+\mathrm{CDT}-)$ and one non-toxigenic (A-B-CDT), were isolated from animals from Pernambuco and Alagoas state, respectively.

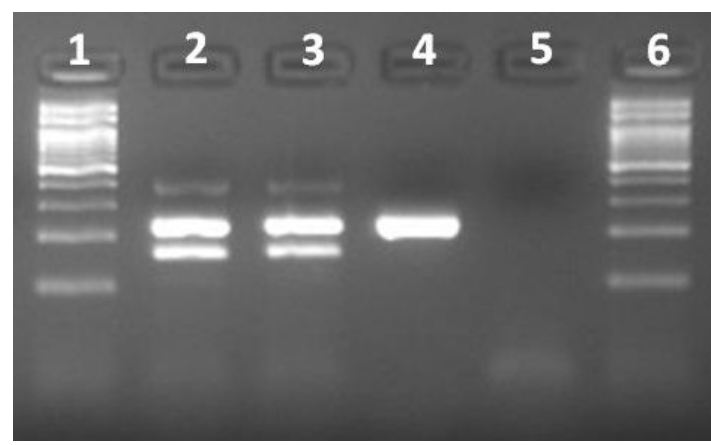

Figure 1. Characterization of the Clostridium difficile isolates by multiplex PCR. First and sixth lane, 100bp ladder. Second lane, $C$. difficile ATCC 9689 (positive control); third lane, toxigenic $(\mathrm{A}+\mathrm{B}+)$ C. difficile isolate; fourth lane, nontoxigenic $(\mathrm{A}-\mathrm{B}-) C$. difficile strain; fifth lane, negative control.

These two wild canids were also positive for $C$. perfringens type A. Both animals were apparently healthy during the sampling, but one of them was under antibiotic therapy due to surgery to repair a fractured pelvis. To the best of the author's knowledge, this is the first report of $C$. difficile in crab-eating fox. A low rate of fecal shedding of $C$. difficile has been described in several wild species, including synanthropic and wild rodents, zebra, procynoids and some wild carnivores (Himsworth et al., 2014, Silva et al., 2013, Álvarez-Pérez et al., 2014, Silva et al., 
2014a,b). Similar to the present study, Silva et al. (2014a) described the isolation of $C$. difficile from an apparently healthy maned wolf (Chrysocyon brachyurus) and from a diarrheic ocelot (Leopardus pardalis), both under antibiotic therapy at the time of collection. The influence of antibiotic administration on the incidence of CDI is well-known in humans and also in some domestic animals (Rodriguez et al., 2016). C. difficile infection (CDI) has been detected also in other non-carnivore species, including elephants and harbor seals (Bojensen et al., 2006, Anderson et al., 2015). Anyway, both C. difficile positive animals in the present study were apparently healthy and, even in the crabeating foxes positive for a toxigenic strain, the stool samples were negative for $\mathrm{A} / \mathrm{B}$ toxins, thus both cases should be interpreted as fecal shedding and not to CDI.

\section{CONCLUSION}

This study suggests that crab-eating foxes could shed $C$. difficile in their feces. It is important to emphasize that this is the first report of $C$. difficile in crab-eating fox. Concerning to the detection of $C$. perfringens, the microorganism may be considered part of the normal intestinal microbiota of these wild carnivores. Additional studies are needed to clarify the role of $C$. perfringens and its virulence factors in wild carnivore species.

\section{REFERENCES}

ÁLVAREZ-PÉREZ， S.; BLANCO， J.L.; MARTÍNEZ-NEVADO, E. et al. Shedding of Clostridium difficile PCR ribotype 078 by zoo animals, and report of an unstable metronidazole-resistant isolate from a zebra foal (Equus quagga burchellii). Vet. Microbiol., v.169, p.218-222, 2014.

ANDERSON, C.E.; HAULENA, M.; ZABEK, E. et al. Clinical and epidemiologic considerations of Clostridium difficile in harbor seals (Phoca vitulina) at a marine mammal rehabilitation center. J. Zoo Wildl. Med., v.46, p.191-197, 2015.

BOJESEN, A.M.; OLSEN, K.E.; BERTELSEN, M.F. Fatal enterocolitis in Asian elephants (Elephas maximus) caused by Clostridium difficile. Vet. Microbiol., v.116, p.329-335, 2006.
CARNIELI JR., P.; CASTILHO, J.; FAHL, W.O. et al. Molecular characterization of rabies virus isolates from dogs and crab-eating foxes in Northeastern Brazil. Virus Res., v.141, p.81-89, 2009.

GOHARI, I.M.; PARREIRA, V.R.; NOWELL, V.J. et al. A novel pore-forming toxin in type A Clostridium perfringens is associated with both fatal canine hemorrhagic gastroenteritis and fatal foal necrotizing enterocolitis. PLoS One, v.10, p.e0122684, 2015.

HENSGENS, M.P.; KEESSEN, E.C.; SQUIRE, M.M. et al. Clostridium difficile infection in the community: a zoonotic disease? Clin. Microbiol. Infect., v.18, p.635-645, 2012.

HIMSWORTH, C.G.; PATRICK, D.M.; MAK, S. et al. Carriage of Clostridium difficile by wild urban Norway rats (Rattus norvegicus) and black rats (Rattus rattus). Appl. Environ. Microbiol., v.80, p.1299-1305, 2014.

KEYBURN, A.L.; BOYCE, J.D.; VAZ, P. et al. NetB, a new toxin that is associated with avian necrotic enteritis caused by Clostridium perfringens. PLoS Pathogens, v.4, p.e26, 2008.

KNETSCH, C.W.; CONNOR, T.R.; MUTREJA, A. et al. Whole genome sequencing reveals potential spread of Clostridium difficile between humans and farm animals in the Netherlands, 2002 to 2011. Euro Surveill., v.19, p.20954, 2014.

LOO, V.G.; BOURGAULT, A.M.; POIRIER, L. et al. Host and pathogen factors for-Clostridium difficile infection and colonization. N. Engl. J. Med., v.365, p.1693-1703, 2011.

OLIVEIRA-FILHO， E.F.; PINHEIRO， J.W.; SOUZA, M.M. et al. Serologic survey of brucellosis in captive neotropical wild carnivores in northeast Brazil. J. Zoo Wildl. Med., v.43, p.384-387, 2012.

RODRIGUEZ, C.; VAN BROECK, J.; TAMINIAU, B. et al. Clostridium difficile infection: early history, diagnosis and molecular strain typing methods. Microb. Pathog., v.97, p.59-78, 2016.

SCHWAN, C.; STECHER, B.; TZIVELEKIDIS, T. et al. Clostridium difficile toxin CDT induces formation of microtubule-based protrusions and increases adherence of bacteria. PLoS Pathog., v.5, p.e1000626, 2009. 
SILVA, R.O.; ALMEIDA, L.R.; OLIVEIRAJUNIOR, C.A. et al. Isolation and genotyping of Clostridium perfringens from free-living South American coati (Nasua nasua). J. Zoo Wildl. Med., v.47, p.333-336, 2016.

SILVA, R.O.; D'ELIA, M.L.; MAGALHÃESSOARES, D.F. et al. Clostridium difficileassociated diarrhea in an ocelot (Leopardus pardalis). Anaerobe, v.20, p.82-84, 2013.

SILVA, R.O.; D'ELIA, M.L.; TOSTESTEIXEIRA, E.P. et al. Clostridium difficile and Clostridium perfringens from wild carnivore species in Brazil. Anaerobe, v.28, p.207-211, 2014a.

SILVA, R.O.; LOBATO, F.C. Clostridium perfringens: a review of enteric diseases in dogs, cats and wild animals. Anaerobe, v.33, p.14-17, 2015.

SILVA, R.O.; RIBEIRO-ALMEIDA, L.; OLIVEIRA-JUNIOR, C.A. et al. Carriage of Clostridium difficile in free-living South American coati (Nasua nasua) in Brazil. Anaerobe, v.30, p.99-101, 2014b.

SOARES, J.F.; DALL'AGNOL, B.; COSTA, F.B. et al. Natural infection of the wild canid, Cerdocyon thous, with the piroplasmid Rangelia vitalii in Brazil. Vet. Parasitol., v.28, p.156-163, 2014.
SOUZA, D.N.; CARNIELI JR, P.; MACEDO, C.I. et al. Phylogenetic analysis of rabies virus isolated from canids in North and Northeast Brazil. Arch. Virol., v.162, p.71-77, 2016.

TUNON, G.I.; MOURA, T.R.; JESUS, A.R. et al. In vitro infection by Leishmania infantum in the peripheral blood mononuclear cell-derived macrophages from crab-eating foxes (Cerdocyon thous). Vet. Parasitol., v.15, p.417-21, 2015.

UZAL, F.A.; FREEDMAN, J.C.; SHRESTHA, A. et al. Towards an understanding of the role of Clostridium perfringens toxins in human and animal disease. Future Microbiol., v.9, p.361377, 2014.

VIEIRA, A.A.S.; GUEDES, R.M.C.; SALVARANI, F.M. et al. Genotyping of Clostridium perfringens isolated from diarrheic piglets. Arq. Inst. Biol., v.75, p.513-516, 2008.

ZEIRA, O.; BRIOLA, C.; KONAR, M. et al. Suspected neurotoxicity due to Clostridium perfringens type $\mathrm{B}$ in a tiger (Panthera tigris). J. Zoo Wildl. Med., v.43, p.666-669, 2012.

ZHANG, Y.; HOU, Z.; MA, J. Hemorrhagic enterocolitis and death in two felines (Panthera tigris altaica and Panthera leo) associated with Clostridium perfringens type A. J. Zoo Wildl. Med., v.43, p.394-396, 2012. 